\title{
PENGARUH MERCHANDISING TERHADAP KEPUASAN DAN LOYALITAS PELANGGAN INDOMARET DI KOTA DENPASAR
}

\author{
Ni Luh Made Kartika Dewi ${ }^{1}$ \\ Eka Sulisyawati \\ ${ }^{1,2}$ Fakultas Ekonomi dan Bisnis Universitas Udayana (Unud), Bali, Indonesia \\ email: kartikadewi667@gmail.com
}

\begin{abstract}
ABSTRAK
Penelitian ini bertujuan untuk mengetahui peran kepuasan pelanggan dalam memediasi pengaruh merchandising terhadap loyalitas pelanggan.Penelitian ini dilakukan di Kota Denpasar dengan jumlah sampel sebanyak 120 sampel. Penentuan sampel menggunakan teknik non probability sampling, dengan metode purposive sampling. Metode pengumpulan data menggunakan kuesioner. Teknik analisis yang digunakan pada penelitian ini adalah teknik analisis jalur (path analysis).Berdasarkan hasil penelitian yang dilakukan, ditemukan bahwa kepuasan pelanggan berpengaruh positif dan signifikan dalam memediasi hubungan antara pengaruh merchandising dengan loyalitas pelanggan Indomaret di Kota Denpasar. Berdasarkan hasil penelitian maka disarankan bagi pihak Indomaret untuk lebih memperhatikan pengelolaan merchandising agar lebih mampumeningkatkan kepuasan pelanggan untuk menjaga dan meningkatkan loyalitas pelanggan.

Kata Kunci : loyalitas pelanggan, kepuasan pelanggan, merchandising
\end{abstract}

\begin{abstract}
This study aims to determine the role of customer satisfaction in mediating the influence of merchandising on customer loyalty. This research was conducted in Denpasar City with a total sample of 120 samples. Determination of sample using non probability sampling technique, with purposive sampling method. Methods of collecting data using a questionnaire. The analysis technique used in this study is path analysis. Based on the results of the research conducted, it was found that customer satisfaction had a positive and significant effect in mediating the relationship between the influence of merchandising and the loyalty of Indomaret customers in Denpasar City. Based on the results of the study, it is recommended for Indomaret to pay more attention to merchandising management in order to be more able to increase customer satisfaction to maintain and increase customer loyalty.

Keywords: customer loyalty, customer satisfaction, merchandising
\end{abstract}




\section{PENDAHULUAN}

Loyalitas pelanggan merupakan hal yang sangat penting untuk diperhatikan dalam sebuah perusahaan. Seorang pemasar sangat mengharapkan akan dapat mempertahankan pelanggannya dalam waktu yang lama, mempertahankan mereka berarti meningkatkan kinerja keuangan dan mempertahankan kelangsungan hidup perusahaan. Apabila perusahaan memiliki seorang pelanggan yang loyal, maka pelanggan tersebut tidak hanya secara terus menerus menggunakan produk atau jasa perusahaan, tetapi dengan sendirinya pelanggan tersebut juga akan merekomendasikannya kepada orang lain sesuai dengan pengalaman yang ia rasakan. Pelanggan yang loyal secara tidak langsung dapat membantu perusahaan dalam mempromosikan produk atau jasa kepada orang-orang terdekatnya. Tentu saja hal ini akan sangat membantu perusahaan untuk mendapatkan pelanggan baru.

Loyalitas pelanggan adalah komitmen pelanggan bertahan secara mendalam untuk berlangganan kembali atau melakukan pembelian ulang produk atau jasa terpilih secara konsisten di masa yang akan datang, meskipun pengaruh situasi dan usaha-usaha pemasaran mempunyai potensi untuk menyebabkan perubahan perilaku (Sangadji dkk., 2013). Pelanggan yang loyal merupakan aset penting bagi perusahaan. Hal ini dapat dilihat dari karakteristik yang dimilikinya. Griffin (2005:31), menyatakan bahwa pelanggan yang loyal memiliki karakteristik melakukan pembelian berulang secara teratur, melakukan pembelian antar lini produk dan jasa, merekomendasikan produk kepada orang lain, dan menunjukkan kekebalan terhadap daya tarik produk sejenis dari pesaing (tidak terpengaruh untuk berbelanja di tempat lain).

Loyalitas pelanggan yang diciptakan dari kepuasan pelanggan merupakan faktor penting dalam kesuksesan perdagangan ritel dan kemampuan toko untuk bertahan. Kepuasan menjadi peran yang sangat penting dalam pembelian suatu produk dan jasa yang dilakukan oleh pelanggan. Menurut Sangadji dkk. (2013:180), pelanggan yang merasa puas pada produk atau jasa yang dibeli dan digunakannya akan kembali menggunakan jasa atau produk yang ditawarkan. Kepuasan pelanggan adalah perasaan senang membandingkan persepsi atau kesan dengan kinerja suatu produk dan harapan-harapannya (Kotler \& Keller, 2009:138). Pelanggan merupakan satu-satunya alasan hidup dan tumbuhnya suatu perusahaan, alasan ini menyebabkan kepuasan pelanggan menjadi prioritas utama bagi perusahaan. Di dukung oleh penelitian dari Hati \& Parlewenti (2017) yang menyatakan bahwa kepuasan pelanggan mempunyai pengaruh signifikan terhadap loyalitas pelanggan. Untuk mencapai kepuasan pelanggan yang tinggi, perusahaan harus tahu kapan dan bagaimana pelanggan puas tentang produk dan jasa.

Dewasa ini dunia usaha di Indonesia sedang berkembang pesat dengan adanya pertumbuhan dan kemajuan ekonomi. Seiring dengan pesatnya laju pertumbuhan ekonomi Indonesia ini, dampak yang tergambar ialah pada bisnis ritel yang semakin banyak. Kondisi seperti ini mengharuskan setiap perusahaan yang bergerak di bidang ritel untuk senantiasa melakukan berbagai strategi agar dapat merebut hati pelanggan (Pasaribu \& Sembiring, 2012). Hingga saat ini, pangsa pasar modern mencapai 30 persen, sedangkan pangsa pasar tradisional 70 
persen. Ini menunjukkan peluang bisnis ritel (pasar modern) cukup menjanjikan, setiap tahun selalu muncul dan berdiri gerai baru ritel di kota-kota besar (Sugiyanto \& Yolanda, 2013). Retailing (usaha eceran) selalu berusaha melakukan berbagai macam strategi, misalnya strategi penawaran diskon, produk murah, kelengkapan produk, dan berbagai strategi lainnya, yang tujuannya untuk menarik minat pelanggan membeli produknya atau melakukan transaksi di tokonya.

Menetapkan pasar sasaran dalam bisnis ritel merupakan prasyarat untuk menetapkan bauran ritel. Menurut (Putra, 2012), bauran pemasaran ritel (retail marketing mix) adalah variabel keputusan pengecer yang digunakan untuk memenuhi kebutuhan pelanggan dan mempengaruhi mereka dalam keputusan pembelian dan dengan demikian mempengaruhi komitmen pelanggan dengan cara menciptakan kepuasan. Untuk dapat menetapkan dan meningkatkan bisnis ritelnya para pengusaha ritel harus memperhatikan bauran-bauran ritel seperti merchandising, harga, lokasi atmosfer toko dan pelayanan. Akan tetapi dalam prakteknya, seringkali ditemui suatu dilema yang dihadapi oleh para pemasar, yaitu adalah bagaimana cara mengembangkan bauran ritel yang tidak hanya efektif memenuhi target pasar, tetapi juga membangun komitmen dan loyalitas pelanggan (Hati \& Parlewenti, 2017).

Semua ritel menghadapi masalah mengenai strategi yang paling dasar yaitu jenis format ritel untuk memperoleh keuntungan yang kompetitif dan dapat menopang keseluruhan rencana kerja ritel tersebut. Komponen yang paling kritis dalam keputusan ini adalah menentukan keberagaman barang dagangan (merchandising) yang akan ditawarkan pada pelanggan untuk diinventariskan dalam inventaris barang dagangan dan keterbatasan luas yang tersedia dalam toko. Merchandising adalah bagian dari retail mix dimana perusahaan melakukan kegiatan pengadaan produk-produk menurut bisnis yang dijalani toko untuk disediakan dalam jumlah, waktu dan harga sesuai sasaran toko atau perusahaan ritel (Ma'ruf, 2006:135). Menurut Leonard, (2012) penerapan merchandising cocok diterapkan untuk semua jenis produk baik produk rokok, makanan, minuman, di merchandising sedemikian rupa hingga menarik pelanggan. Pilihan gambar, tulisan, tata letak, ukuran, warna, pencahayaan, dan pernak pernik aspek merchandising ternyata sungguh luar biasa. Semakin dekat dengan gerai, terlebih lagi setelah masuk gerai, pengunjung makin terbius dengan segala penampilan produk yang ditata apik, diperagakan secara demonstrative, akhirnya mereka tanpa sadar akan mengeluarkan dompetnya, dan terjadilah transaksi. Merchandising merupakan "senjata menarik perhatian" yang paling ampuh yang saat ini masih sering terlupakan dan belum dioptimalkan untuk meningkatkan penjualan dan pangsa pasar dalam menciptakan kepuasan yang akan berdampak terhadap loyalitas pelanggan.

Herawati dkk. (2013) menyatakan bahwa merchandising, basic principles, dan service memiliki pengaruh yang positif dan signifikan terhadap kepuasan pelanggan. Penelitian dari Hati \& Parlewenti (2017) menemukan bahwa merchandising berpengaruh signifikan terhadap kepuasan pelanggan dan merchandising juga mempunyai pengaruh signifikan terhadap loyalitas pelanggan. Pengelolaan barang dagangan (merchandising) adalah proses 
penanganan kreatif dalam upaya untuk mempresentasikan daya tarik penjualan ritel (Utami, 2010:193).

Sehubungan dengan hal tersebut, maka penelitian ini meneliti tentang aplikasi pemasaran ritel melalui variabel merchandising dalam kaitannya untuk menciptakan kepuasan dan loyalitas pelanggan dengan parameter merchandising (Semuel, 2006) seperti : pengadaan merchandise; kelengkapan produk; pemberian diskon; penataan layout produk. Konsumen pada dasarnya datang ke perusahaan ritel untuk mencari produk-produk yang dibutuhkan. Gerai harus mampu memberikan citra yang baik kepada konsumen dengan menata sekreatif mungkin produk dalam gerai agar keliatan menarik dan menyediakan produk yang dibutuhkan dan diinginkan oleh para konsumen (Utami, 2010:86).

Sejauh ini penelitian tentang pengaruh merchandising terhadap kepuasan dan loyalitas pelanggan masih jarang ditemukan. Hal ini memotivasi peneliti untuk melakukan penelitian tentang kepuasan dan loyalitas pelanggan ritel modern melalui variabel merchandising, mengingat semakin banyaknya perusahaan ritel modern baru yang beroperasi di Indonesia. Salah satu industri ritel modern tersebut bernama Indomaret yang merupakan salah satu anak perusahaan Salim Group. Indomaret merupakan jaringan minimarketyang menyediakan kebutuhan pokok dan kebutuhan sehari-hari. Berdiri sejak tahun 1988, dikelola oleh PT. Indomarco Prismatama. Hingga Februari 2018, Indomaret memiliki 15.456 gerai, terdiri dari $60 \%$ milik sendiri dan $40 \%$ milik masyarakat. Semuanya tersebar di Jawa, Bali, Madura dan Sumatra. Gerai Indomaret ditempatkan di lokasi-lokasi strategis sehingga mudah dijangkau. Khusus di Bali terdapat sekitar 488 gerai, dan di Kota Denpasar hingga tahun 2016 gerai Indomaret ada sekitar 47 gerai.

Tabel 1. Jumlah Gerai Indomaret Di Kota Denpasar Tahun 2016

\begin{tabular}{lccc}
\hline \multicolumn{1}{c}{ Wilayah } & Regular & Frenchise & Total \\
\hline Denpasar Barat & 9 & 5 & 14 \\
Denpasar Timur & 9 & 4 & 13 \\
Denpasar Selatan & 6 & 3 & 9 \\
Denpasar Utara & 7 & 4 & 11 \\
& & & 47 \\
\hline
\end{tabular}

Sumber: Indomaret Denpasar, 2016

Keberadaan pasar modern seperti Alfamart dapat menjadi sebuah ancaman bagi Indomaret karena Alfamart tidak lain adalah pesaing utama Indomaret, ini merupakan alasan mengapa Indomaret dipilih sebagai obyek penelitian karena pada saat ini Indomaret telah banyak membuka gerainya di berbagai kota dan provinsi. Jumlah gerai Alfamart di Indonesia sekitar 10.000 gerai, di bandingkan dengan Indomaret yang berjumlah lebih dari 15.000 gerai hingga tahun 2018, seharusnya kepuasan dan loyalitas pelanggan saat ini lebih kepada Indomaret. Walaupun Alfamart di awal lebih unggul, akan tetapi dengan persaingan yang ketat Indomaret mampu bersaing dan sekarang Indomaret unggul dalam strategi merchandising dibandingkan Alfamart karena Indomaret dalam setiap gerai menyediakan lebih dari 5000 produk food, nonfood, general merchandise dan fresh product dengan harga hemat, untuk memenuhi kebutuhan sehari-hari 
konsumen (Indomaret, 2018) sedangkan Alfamart hanya menyediakan 4000 produk yang dijual di dalam gerainya, diungkapkan oleh Nur Rachman selaku Corporate Communication General Manager Alfamart (Alfamart, 2018).

Kelengkapan dan Keragaman produk yang ditawarkan, membuat Indomaret menjadi salah satu ritel modern yang sangat berorientasi pada kepuasan pelanggan dalam menciptakan loyalitas terhadap gerai. Berkaitan dengan perilaku belanja konsumen yang cenderung untuk memenuhi kebutuhan sehari-hari maka merupakan suatu keharusan bagi Indomaret untuk membuat strategi merchandising menjadi menarik untuk menyentuh hati konsumen agar melakukan suatu pembelian serta memuaskan konsumen sehingga konsumen akan melakukan pembelian kembali. Penulis memilih Indomaret yang ada di Kota Denpasar sebagai tempat melaksanakan penelitian karena kota Denpasar lokasinya sangat strategis, mudah dijangkau dan merupakan jumlah penduduk paling banyak dibandingkan dengan kota lain yang ada di Bali dan Denpasar juga merupakan ibu kota dari provinsi Bali sendiri.

Berdasarkan gambaran yang dikemukakan, maka Indomaret di kota Denpasar dipandang sangat representatif untuk mewakili kelompok ritel modern, yang menjadikan kepuasan dan loyalitas pelanggannya sebagai tujuan perusahaan melalui pengorganisasian pemasaran ritel menimbulkan kecenderungan teoritik yang menarik untuk diteliti. Untuk itu dalam penelitian ini pengaruh merchandising akan digunakan untuk mengetahui kepuasan pelanggan dan loyalitas pelanggan terhadap Indomaret yang ada di Kota Denpasar Bali.

Penelitian dari Putra (2012) menemukan bahwa elemen-elemen dari bauran pemasaran ritel berpengaruh positif dan signifikan terhadap loyalitas pelanggan. Penelitian yang dilakukan oleh Hermawati (2013) menyatakan bahwa masingmasing variabel dari retail marketing mix berpengaruh positif dan signfikan terhadap loyalitas pelanggan, namun variabel harga berpengaruh positif tetapi tidak signifikan terhadap loyalitas pelanggan. Hal ini diperkuat lagi oleh penelitian dari Hati \& Parlewenti (2017) yang menemukan bahwa merchandising mempunyai pengaruh positif dan signifikan terhadap loyalitas pelanggan. Berdasarkan hasil penelitian yang telah diuraikan sebelumnya maka dapat dirumuskan hipotesis penelitian sebagai berikut.

$\mathrm{H}_{1}$ : Merchandising berpengaruh positif dan signifikan terhadap loyalitas pelanggan.

Bauran pemasaran ritel terdiri atas beberapa elemen yang dapat mempengaruhi kepuasan pelanggan dalam membeli suatu produk, penelitian Pasaribu \& Sembiring (2012) menemukan bahwa bauran pemasaran ritel berpengaruh positif dan signifikan terhadap kepuasan pelanggan. Herawati dkk. (2013) menyatakan bahwa merchandising, basic principles, dan service memiliki pengaruh yang positif dan signifikan terhadap kepuasan pelanggan. Penelitian yang ditemukan Faizul (2008) bahwa indikator bauran pemasaran ritel berpengaruh positif dan signifikan terhadap kepuasan pelanggan, namun indikator harga dan pelayanan eceran berpengaruh tidak signifikan terhadap kepuasan pelanggan. Penelitian dari Yulianti (2017) menemukan bahwa merchandising berpengaruh positif dan signifikan terhadap kepuasan pelanggan dan diperkuat lagi oleh penelitian Hati \& Parlewenti (2017) menyatakan bahwa variable 
merchandising berpengaruh signifikan terhadap kepuasan pelanggan. Hasil ini menunjukkan bahwa ketepatan strategi untuk bauran pemasaran ritel khususnya merchandising dapat memberikan rasa puas terhadap pelanggan, dimana itu merupakan salah satu tujuan dari perusahaan. Berdasarkan hasil penelitian yang telah diuraikan sebelumnya maka dapat dirumuskan hipotesis penelitian sebagai berikut.

$\mathrm{H}_{2}$ : Merchandising berpengaruh positif dan signifikan terhadap kepuasan pelanggan.

Berdasarkan penelitian dari Musanto (2004) menunjukkan bahwa kepuasan pelanggan mempunyai pengaruh positif dan signifikan terhadap loyalitas pelanggan. Penelitian Wahyuni (2008) juga menunjukkan bahwa variable kepuasan mempunyai pengaruh positif dan signifikan terhadap loyalitas. Penelitian Rachmawati (2014) menemukan bahwa kepuasan pelanggan berpengaruh secara positif dan signifikan terhadap loyalitas pelanggan. Penelitian Cahyana \& Sukaatmadja (2017) juga menemukan bahwa kepuasan pelanggan berpengaruh secara positif dan signifikan terhadap loyalitas pelanggan. Ketika pelanggan telah merasa puas membeli atau menggunakan suatu produk maka pelanggan tersebut pasti tidak akan ragu untuk melakukan pembelian di tempat yang sama. Diperkuat lagi oleh penelitian (Hati \& Parlewenti, 2017) menemukan bahwa kepuasan pelanggan mempunyai pengaruh positif dan signifikan terhadap loyalitas pelanggan. Berdasarkan hasil penelitian yang telah diuraikan sebelumnya maka dapat dirumuskan hipotesis penelitian sebagai berikut:

$\mathrm{H}_{3}$ : Kepuasan pelanggan berpengaruh positif dan signifikan terhadap loyalitas pelanggan.

Penelitian yang dilakukan oleh Hati \& Parlewenti (2017), Hidayat \& Melinda (2009), serta Dei \& Sukaatmadja (2015), menyatakan bahwa kepuasan pelanggan mampu memediasi secara positif dan signifikan terhadap suatu variabel.

Berdasarkan dari hasil penelitian sebelumnya, maka pada penelitian ini dapat ditarik hipotesis sebagai berikut :

$\mathrm{H}_{4}$ : Kepuasan pelanggan berpengaruh positif signifikan dalam memediasi merchandising dengan loyalitas pelanggan.

Menetapkan pasar sasaran dalam bisnis ritel merupakan prasyarat untuk menetapkan bauran ritel. Menurut (Putra, 2012), bauran pemasaran ritel (retail marketing mix) adalah variabel keputusan pengecer yang digunakan untuk memenuhi kebutuhan pelanggan dan mempengaruhi mereka dalam keputusan pembelian dan dengan demikian mempengaruhi komitmen pelanggan dengan cara menciptakan kepuasan. Untuk dapat menetapkan dan meningkatkan bisnis ritelnya para pengusaha ritel harus memperhatikan bauran-bauran ritel seperti merchandising, harga, lokasi atmosfer toko dan pelayanan. Akan tetapi dalam prakteknya, seringkali ditemui suatu dilema yang dihadapi oleh para pemasar, yaitu adalah bagaimana cara mengembangkan bauran ritel yang tidak hanya efektif memenuhi target pasar, tetapi juga membangun komitmen dan loyalitas pelanggan (Hati \& Parlewenti, 2017). 


\section{METODE PENELITIAN}

Penelitian ini dilakukan di Indomaret Kota Denpasar yang merupakan ibukota Provinsi Bali dengan penduduk yang padat karena memiliki jumlah penduduk paling banyak dibandingkan dengan kota-kota lainnya dengan pertimbangan bahwa Indomaret di Kota Denpasar dikategorikan sebagai ritel modern yang telah menerapkan strategi merchandising dalam mencapai kepuasan dan loyalitas pelanggan.

Obyek dari penelitian ini adalah pengaruhmerchandising $(\mathrm{X})$ terhadap loyalitas pelanggan $\left(\mathrm{Y}_{2}\right)$, pengaruh merchandising $(\mathrm{X})$ terhadap kepuasan pelanggan $\left(\mathrm{Y}_{1}\right)$, pengaruh kepuasan pelanggan $\left(\mathrm{Y}_{1}\right)$ terhadap loyalitas pelanggan $\left(\mathrm{Y}_{2}\right)$, serta peran kepuasan pelanggan $\left(\mathrm{Y}_{1}\right)$ dalam memediasi pengaruh merchandising $(\mathrm{X})$ terhadap loyalitas pelanggan $\left(\mathrm{Y}_{2}\right)$ pada pelanggan Indomaret di Kota Denpasar.

\section{Tabel 2.}

\section{Identifikasi Variabel}

\begin{tabular}{|c|c|c|c|}
\hline Variabel Penelitian & Indikator & Notasi & Referensi \\
\hline $\begin{array}{l}\text { Loyalitas Pelanggan } \\
\text { (Variabel Dependen) } \\
\text { (Y2) }\end{array}$ & $\begin{array}{l}\text { Pembelian Ulang }\left(\mathrm{Y} 2_{1}\right) \\
\text { Membeli antar lini produk dan } \\
\text { jasa }\left(\mathrm{Y} 2_{2}\right) \\
\text { Merekomendasikan }\left(\mathrm{Y}_{3}\right) \\
\text { Tidak Terpengaruh }\left(\mathrm{Y} 2_{4}\right)\end{array}$ & $\mathrm{Y}_{2}$ & $\begin{array}{l}\text { Mardalis (2005), } \\
\text { Faizul (2008) } \\
\text { Rachmawati (2014) } \\
\text { Sangadji dkk. } \\
\text { (2013) }\end{array}$ \\
\hline $\begin{array}{l}\text { Kepuasan Pelanggan } \\
\text { (Variabel Mediasi) } \\
\text { (Y1) }\end{array}$ & $\begin{array}{l}\text { Kualitas Produk }\left(\mathrm{Y} 1_{1}\right) \\
\text { Fasilitas Gerai }\left(\mathrm{Y} 1_{2}\right) \\
\text { Pelayanan Karyawan }\left(\mathrm{Y}_{3}\right) \\
\text { Lokasi Gerai }\left(\mathrm{Y} 1_{4}\right)\end{array}$ & $\mathrm{Y}_{1}$ & $\begin{array}{l}\text { Putra (2012), } \\
\text { Aryani \& Rosinta, } \\
(2010) \text {, (Martınez- } \\
\text { Ruiz, et al. (2010) }\end{array}$ \\
\hline $\begin{array}{l}\text { Merchandising } \\
\text { (Variabel Bebas) } \\
\text { (X1) }\end{array}$ & $\begin{array}{l}\text { Pengadaan produk } \\
\text { (merchandise })\left(\mathrm{X} 1_{1}\right) \\
\text { Kelengkapan produk }\left(\mathrm{X}_{2}\right) \\
\text { Pemberian Diskon }\left(\mathrm{X}_{3}\right) \\
\text { Penataan Layout } \text { Produk }\left(\mathrm{X}_{4}\right)\end{array}$ & $\mathrm{X}_{1}$ & Semuel (2006) \\
\hline
\end{tabular}

Sumber: Data diolah, 2018

Populasi dalam penelitian ini adalah masyarakat Kota Denpasar yang berbelanja di Indomaret Kota Denpasar yang jumlahnya tidak diketahui. Populasi dalam penelitian ini bersifat infinite (tidak terbatas).Penelitian ini menggunakan 12 indikator sehingga dengan menggunakan estimasi berdasarkan jumlah parameter diperoleh ukuran sampel sebesar 60-120 responden. Penentuan sampel sebesar 120 responden sesuai dengan ketentuan pengambilan sampel untuk memperoleh hasil yang maksimal yaitu digunakan $\geq 100$ sampel.

Dalam penelitian ini teknik analisis yang digunakan adalah teknik analsis jalur (path analysis).

Persamaan Sub-struktural 1

$$
\mathrm{Y} 1=\beta 2 \mathrm{X}+\mathrm{e}_{1}
$$

Persamaan Sub-struktural 2

$$
\mathrm{Y} 2=\beta 1 \mathrm{X}+\beta 3 \mathrm{Y} 1+\mathrm{e}_{2}
$$

Keterangan :

$$
\mathrm{X}=\text { Merchandising }
$$




$$
\begin{aligned}
& \text { Y1 = KepuasanPelanggan } \\
& \text { Y2 = LoyalitasPelanggan } \\
& \beta 1, \beta 2, \beta 3=\text { koefisienregresivariabel } \\
& \mathrm{e}=\text { error }
\end{aligned}
$$

Uji Sobel digunakan dengan menguji kekuatan pengaruh tidak langsung variabel Merchandising (X) terhadap variabel Loyalitas Pelanggan $\left(\mathrm{Y}_{2}\right)$ melalui variabel Kepuasan Pelanggan $\left(\mathrm{Y}_{1}\right)$. Pengaruh tidak langsung variabel Merchandising (X) terhadap variabel Loyalitas Pelanggan (Y2) melalui variabel Kepuasan Pelanggan $\left(\mathrm{Y}_{1}\right)$ dihitung dengan cara mengalikan koefisien jalur $\mathrm{X}$ terhadap $\mathrm{Y}_{1}$ (a) dengan koefisien jalur $\mathrm{Y}_{1}$ terhadap $\mathrm{Y}_{2}$ (b) atau ab. Standar error koefisien a dan $b$ ditulis dengan $S_{a}$ dan $S_{b}$, besarnya standar error tidak langsung (indirect effect) $\mathrm{S}_{\mathrm{ab}}$.

Standar error tidak langsung (indirect effect) $\mathrm{S}_{\mathrm{ab}}$ dihitung dengan rumus berikut:

$$
S=\sqrt{ }{ }^{2} S^{2}+{ }^{2} S^{2}+S^{2} S^{2}
$$

Untuk menguji signifikansi pengaruh tidak langsung maka nilai $\mathrm{z}$ dari koefisien ab dihitung denan rumus sebagai berikut:

$$
Z=\frac{a b}{S a b}
$$

Keterangan:

$\mathrm{S}=$ besarnya standar error tidak langsung

$\mathrm{S}=$ standar error koefisien a

$\mathrm{S} \quad=$ standar error koefisien $\mathrm{b}$

$=$ koefisien jalur $\mathrm{X}_{1}$ terhadap $\mathrm{Y}_{1}$

$=$ koefisien jalur $Y_{1}$ terhadap $Y_{2}$

$=$ hasil kali koefisien jalur $\mathrm{X}$ terhadap koefisien jalur $\mathrm{Y}_{1}$ (a) dengan jalur $\mathrm{Y}_{1}$ terhadap $\mathrm{Y}_{2}(\mathrm{~b})$

\section{HASIL DAN PEMBAHASAN}

Karakteristik responden dapat dikelompokkan berdasarkan jenis kelamin, yaitu laki-laki dengan persentase sebesar 33,3 persen dan perempuan dengan persentase sebesar 66,7 persen. Lalu berdasarkan usia, menunjukkan bahwa mayoritas responden berusia 21-25 tahun dengan persentase 80 persen, usia 18-20 tahun dengan persentase sebesar 16,7 persen dan usia 26-30 tahun dengan persentase sebesar 3,3 persen, serta usia diatas 30 tahun sebesar 0 persen. Selanjutnya mayoritas responden berprofesi sebagai mahasiswa/i dengan persentase sebesar 68,34 persen, lalu responden yang berprofesi sebagai karyawan swasta sebesar 25,83 persen, dan yang berprofesi sebagai pengusaha/wirausaha sebesar 2,5 persen, terdapat juga responden yang berprofesi sebagai pegawai negeri dengan persentase sebesar 0,83 persen dan berprofesi lainnya, yaitu bidan, perawat dengan persentase 2,5 persen.

Suatu instrumen dalam penelitian dikatakan valid apabila mampu mengukur apa yang ingin diukur. Suatu instrumen dikatakan valid apabila memiliki koefisien korelasi antara butir dengan skor total dalam instrumen tersebut lebih besar dari 0,30 dengan tingkat kesalahan Alpha 0,05. Tabel 4. berikut menyajikan hasil uji validitas instrumen penelitian. 
Tabel 4.

Hasil Uji Validitas

\begin{tabular}{ccccc}
\hline No. & Variabel & $\begin{array}{c}\text { Item } \\
\text { Pernyataan }\end{array}$ & $\begin{array}{c}\text { Korelasi Item } \\
\text { Total }\end{array}$ & Keterangan \\
\hline 1 & Loyalitas Pelanggan (Y2) & $\mathrm{Y}_{2.1}$ & 0,876 & Valid \\
& & $\mathrm{Y}_{2.2}$ & 0,781 & Valid \\
& & $\mathrm{Y}_{2.3}$ & 0,918 & Valid \\
& & $\mathrm{Y}_{2.4}$ & 0,858 & Valid \\
& \multirow{2}{*}{ Kepuasan Pelanggan (Y1) } & $\mathrm{Y}_{1.1}$ & 0,867 & Valid \\
& & $\mathrm{Y}_{1.2}$ & 0,868 & Valid \\
& & $\mathrm{Y}_{1.3}$ & 0,835 & Valid \\
& \multirow{3}{*}{3} & $\mathrm{Y}_{1.4}$ & 0,840 & Valid \\
& \multirow{2}{*}{ Merchandising (X) } & $\mathrm{X}_{1.1}$ & 0,870 & Valid \\
& & $\mathrm{X}_{1.2}$ & 0,809 & Valid \\
& & $\mathrm{X}_{1.3}$ & 0,838 & Valid \\
& & $\mathrm{X}_{1.4}$ & 0,898 & Valid \\
\hline
\end{tabular}

Sumber:Data diolah, 2018

Instrumen yang reliabel adalah instrumen yang digunakan beberapa kali dan tetap ada kesamaan data dalam waktu yang berbeda. Hasil uji reliabilitas pada penelitian ini dapat dilihat pada Tabel 5. berikut ini.

Tabel 5.

Hasil Uji Reliabilitas

\begin{tabular}{cccc}
\hline No. & Variabel & Cronbadh'sAlpha & Keterangan \\
\hline 1 & Loyalitas Pelanggan (Y2) & 0,878 & Reliabel \\
2 & Kepuasan Pelanggan (Y1) & 0,874 & Reliabel \\
3 & Merchandising (X) & 0,867 & Reliabel \\
\hline
\end{tabular}

Sumber:Data diolah, 2019

Hasil uji reliabilitas pada Tabel 5. menunjukkan bahwa ketiga instrumen penelitian memiliki koefisien Cronbach's Alpha lebih dari 0,60. Hal ini dapat dikatakan, apabila semua variabel instrumen penelitian nilai koefisiennya $\geq 0,60$ maka instrumen tersebut adalah reliabel, sehingga dapat digunakan dalam penelitian ini.

Berdasarkan hasil analisis jalur sub-struktur 1 seperti yang disajikan,maka persamaan strukturnya adalah sebagai berikut:

$$
\begin{aligned}
& \mathrm{Y} 1=\beta_{2} \mathrm{X}+\mathrm{e}_{1} \\
& \mathrm{Y} 1=0,668 \mathrm{X}+\mathrm{e}_{1}
\end{aligned}
$$

Nilai $\beta_{2}$ adalah sejumlah 0,668 berarti merchandising berpengaruh positif terhadap kepuasan pelanggan, hal ini menunjukkan bahwa apabila variable merchandising meningkat maka kepuasan pelanggan Indomaret di Kota Denpasar akan meningkat sebanyak 0,668.

Berdasar kan hasil analisis jalur sub-struktur 2 seperti yang disajikanmaka di dapatpersamaanstrukturalsebagaiberikut:

$$
\mathrm{Y} 2=0,403 \mathrm{X}+0,425 \mathrm{Y} 1+\mathrm{e}_{2}
$$


Nilai $\beta_{1}$ sejumlah 0,403 berarti merchandising berpengaruh positif terhadap loyalitas pelanggan, apabila variabel merchandising meningkat maka meningkatkan variabel loyalitas pelanggan Indomaret di Kota Denpasar sebanyak 0,403 .

Nilai $\beta_{3}$ sejumlah 0,425 berarti kepuasan pelanggan berpengaruh positif terhadap loyalitas pelanggan, hal ini berarti apabila variabel kepuasan pelanggan meningkat maka variabel loyalitas pelanggan Indomaret di Kota Denpasar akan meningkat sebanyak 0,425 .

Perhitungan dari nilai standar eror berdasarkan model hasil analisis jalur 1 dan analisis jalur 2 adalah sebagai berikut:

$$
\begin{aligned}
& P e_{i}=\sqrt{1}-R^{2}{ }^{2} \\
& \mathrm{Pe}_{1}=\sqrt{1-\mathrm{R}_{1}^{2}}=\sqrt{1}-0,447=\sqrt{0,553}=0,744 \\
& \mathrm{Pe}_{2}=\sqrt{1} 1-\mathrm{R}_{2}{ }^{2}=\sqrt{ } 1-0,572=\sqrt{ } 0,428=0,654
\end{aligned}
$$

Berdasarkan hasil perhitungan pengaruh eror $\left(\mathrm{Pe}_{\mathrm{i}}\right)$, maka hasil pengaruh error $\left(\mathrm{Pe}_{1}\right)$ yang di dapat sebanyak 0,744 dan pengaruh eror $\left(\mathrm{Pe}_{2}\right)$ sebanyak 0,654 . Setelah menganalisis $\mathrm{e}_{1}$ dan $\mathrm{e}_{2}$, maka didapat perhitungan koefisien determinasi total sebagai berikut:

$$
\begin{aligned}
\mathrm{R}^{2} \mathrm{~m} & =1-\left(\mathrm{Pe}_{1}\right)^{2}\left(\mathrm{Pe}_{2}\right)^{2} \ldots \ldots \\
& =1-(0,744)^{2}(0,654)^{2} \\
& =1-0,554 \times 0,428 \\
& =0,763
\end{aligned}
$$

Nilai determinasi total sebesar 0,763 memiliki arti bahwa 76 persen variabel loyalitas pelanggan dipengaruhi oleh variabel merchandising dan kepuasan pelanggan, sisanya sebesar 24 persen dijelaskan oleh faktor lain di luar model yang dibentuk.

Pengaruh variabel merchandising (X) terhadap loyalitas pelanggan (Y2):

$$
\mathrm{X} \rightarrow \mathrm{Y} 2=0,403
$$

Pengaruh variabel merchandising terhadap kepuasan pelanggan (Y1)

$$
\mathrm{X} \rightarrow \mathrm{Y} 1=0,668
$$

Pengaruh variabel kepuasan pelanggan (Y1) terhadap loyalitas pelanggan (Y2) :

$$
\mathrm{Y} 1 \rightarrow \mathrm{Y} 2=0,425
$$

Pengaruh variabel merchandising (X) terhadap loyalitas pelanggan (Y2) dengan kepuasan pelanggan (Y1) sebagai variabel perantara:

$$
\begin{aligned}
\mathrm{X} \rightarrow \mathrm{Y} 1 \rightarrow \mathrm{Y} 2 & =(0,668) \times(0,425) \\
& =0,284
\end{aligned}
$$

Untuk memahami pengaruh total (total effect) dapat dilakukan dengan menambah pengaruh langsung merchandising terhadap loyalitas pelanggan lalu mengalikan pengaruh langsung merchandising terhadap kepuasan pelanggan dengan pengaruh langsung kepuasan pelanggan terhadap loyalitas pelanggan.

Total pengaruh variabel $\mathrm{X}$ terhadap $\mathrm{Y} 2$ melalui $\mathrm{Y} 1$ dapat dirumuskan sebagai berikut:

$$
\begin{aligned}
\text { Total effect } & =0,403+(0,668 \times 0,425) \\
& =0,403+0,284 \\
& =0,687
\end{aligned}
$$


Berdasarkan hasil pengolahan data yang terlihat diperoleh nilai $\mathrm{F}$ sebesar 78,244 dengan nilai (sig) $=0,000$. Oleh karena nilai sig $0,000<0,05$, maka dapat disimpulkan bahwa $\mathrm{H}_{0}$ ditolak dan $\mathrm{H}_{1}$ diterima. Artinya bahwa variabel merchandising dan kepuasan pelanggan berpengaruh secara simultan dan signifikan terhadap loyalitas pelanggan.

Berdasarkan hasil olah data diperoleh nilai probabilitas signifikansi sebesar 0,000 dengan nilai koefisien beta 0,403 , dengan nilai t sebesar 4,955. Dengan tingkat signifikasi $0,000<0,05$, maka $\mathrm{H}_{0}$ ditolak dan $\mathrm{H}_{1}$ diterima. Hasil ini mempunyai arti bahwa merchandising berpengaruh secara positif dan signifikan terhadap loyalitas pelanggan.

Berdasarkan hasil olah data diperoleh nilai probabilitas signifikansi sebesar 0,000 dengan nilai koefisien beta 0,668 , dengan nilai t sebesar 9,763. Dengan tingkat signifikasi $0,000<0,05$, maka $\mathrm{H}_{0}$ ditolak dan $\mathrm{H}_{1}$ diterima. Hasil ini mempunyai arti bahwa merchandising berpengaruh secara positif dan signifikan terhadap kepuasan pelanggan.

Berdasarkan hasil olah data diperoleh nilai probabilitas signifikansi sebesar 0,000 dengan nilai koefisien beta 0,425 , dengan nilai t sebesar 5,231. Dengan tingkat signifikasi $0,000<0,05$, maka $\mathrm{H}_{0}$ ditolak dan $\mathrm{H}_{1}$ diterima. Hasil ini mempunyai arti bahwa kepuasan pelanggan berpengaruh secara positif dan signifikan terhadap kepuasan pelanggan.

Diagram jalur peran kepuasan pelanggan dalam memediasi merchandising terhadap loyalitas pelanggan pada hipotesis penelitian ini dapat dihitung besaran pengaruh langsung, pengaruh tidak langsung serta pengaruh total antar variabel. Untuk perhitungan antar variabel dirangkum pada Tabel 6.

Tabel 6.

Pengaruh Langsung, Pengaruh Tidak Langsung dan Pengaruh Total

\begin{tabular}{cccc}
\hline $\begin{array}{c}\text { Pengaruh } \\
\text { Variabel }\end{array}$ & $\begin{array}{c}\text { Pengaruh } \\
\text { Langsung }\end{array}$ & $\begin{array}{c}\text { Pengaruh } \\
\text { Tidak } \\
\text { Langsung } \\
(\mathbf{Y} \mathbf{1})=\left(\boldsymbol{\beta}_{\mathbf{2}} \mathbf{X} \boldsymbol{\beta}_{\mathbf{3}}\right)\end{array}$ & $\begin{array}{c}\text { Peran } \\
\text { Total }\end{array}$ \\
\hline $\begin{array}{c}\text { Merchandising } \\
(\mathrm{X}) \rightarrow \text { Loyalitas }\end{array}$ & 0,403 & 0,284 & 0,687 \\
$\begin{array}{c}\text { Pelanggan (Y2) } \\
\text { Merchandising }\end{array}$ & 0,668 & - & 0,668 \\
$\begin{array}{c}\text { (X) } \rightarrow \text { Kepuasan } \\
\text { Pelanggan (Y1) } \\
\text { Kepuasan }\end{array}$ & 0,425 & - & 0,425 \\
$\begin{array}{c}\text { Pelanggan (Y1) } \\
\rightarrow \text { Loyalitas } \\
\text { Pelanggan }\end{array}$ & & & \\
\hline
\end{tabular}

Sumber:Data diolah, 2018

Analisis direct effect, indirect effect, dan total effect digunakan untuk melihat pengaruh kekuatan antar konstruk, baik yang secara langsung, tidak langsung, maupun pengaruh totalnya. Berdasarkan Tabel 6. maka dapat diartikan bahwa variabel merchandising memiliki pengaruh langsung terhadap variabel loyalitas pelanggan sebesar 0,403 dan pengaruh secara tidak langsung sebesar 0,284, variabel merchandising memiliki pengaruh secara langsung terhadap 
variabel kepuasan pelanggan sebesar 0,668. Pada variabel kepuasan pelanggan memiliki pengaruh secara langsung terhadap variabel loyalitas pelanggan sebesar 0,425 . Hal ini dapat berarti bahwa pengaruh variabel merchandising dengan loyalitas pelanggan akan meningkat apabila pengaruh tersebut dijembatani oleh variabel kepuasan pelanggan. Merchandising juga memiliki andil sebagai variabel mediasi sebagian atau parsial dimana tanpa adanya pemediasi merchandising terhadap loyalitas pelanggan sudah memengaruhi secara postif dan signifikan.

Pengaruh total dalam penelitian ini menunjukkan jumlah pengaruh dari pengaruh langsung dan tidak langsung antar variabel, dimana pengaruh total merupakan jumlah pengaruh langsung ditambah pengaruh tidak langsung. Tabel 6 menunjukkan variabel kepuasan pelanggan bersaing sebagai variabel perantara antara variabel merchandising dengan loyalitas pelanggan sebesar 0,284, sehingga pengaruh total antara variabel merchandising dengan loyalitas pelanggan sebesar 0,687 dan sisanya dijelaskan oleh variabel lain.

Uji Sobel digunakan dengan menguji kekuatan pengaruh tidak langsung variabel Merchandising (X) terhadap variabel LoyalitasPelanggan ( $\left.\mathrm{Y}_{2}\right)$ melalui variabel KepuasanPelanggan $\left(\mathrm{Y}_{1}\right)$. Pengaruh tidak langsung variabel Merchandising (X) terhadap variabel LoyalitasPelanggan (Y2) melalui variabel KepuasanPelanggan $\left(\mathrm{Y}_{1}\right)$ dihitung dengan cara mengalikan koefisien jalur $\mathrm{X}$ terhadap $Y_{1}$ (a) dengan koefisien jalur $Y_{1}$ terhadap $Y_{2}$ (b) atau ab. Standar error koefisien a dan $b$ ditulis dengan $S_{a}$ dan $S_{b}$, besarnya standar error tidak langsung (indirect effect) $\mathrm{S}_{\mathrm{ab}}$.

Dalam melakukan pengujian signifikansi peran mediasi variabel kepuasan pelanggan dapat menggunakan rumus uji sobel. Berdasarkan diagram jalur yang ada, maka dapat dihitung standar error koefisien a dan $b$ ditulis dengan $S_{a}$ dan $S_{b}$, besarnya standar error tidak langsung (indirect effect) $S_{a b}$ dapat dihitung sebagai berikut:

Keterangan :

$$
\begin{aligned}
& S_{a b}=\text { besarnya standar error tidak langsung } \\
& S_{a}=0,066 \\
& S_{b}=0,093 \\
& a=0,668 \\
& b=0,425 \\
& S \quad=\sqrt{ }{ }^{2} S^{2}+{ }^{2} S^{2}+S^{2} S^{2} \\
& S \quad=\sqrt{ }\left(0,425^{2}\right)\left(0,066^{2}\right)+\left(0,668^{2}\right)\left(0,093^{2}\right)+\left(0,066^{2}\right)\left(0,093^{2}\right) \\
& S \quad=\sqrt{ }(0,1806)(0,0044)+(0,44620(0,0086)+(0,0044)(0,0086) \\
& S \quad=\sqrt{ } 0,0008+0,0038+0,0000 \\
& S \quad=\sqrt{ } 0,0047 \\
& S \quad=0,068439
\end{aligned}
$$

Untuk menguji signifikansi pengaruh tidak langsung maka diperlukan untuk melakukan penghitungan nilai $\mathrm{Z}$ dari koefisien ab dengan rumus sebagai berikut:

$$
\begin{aligned}
& Z=\frac{a b}{3 a b} \\
& \text { Keterangan : } \\
& \mathrm{S} \quad=0,068439
\end{aligned}
$$




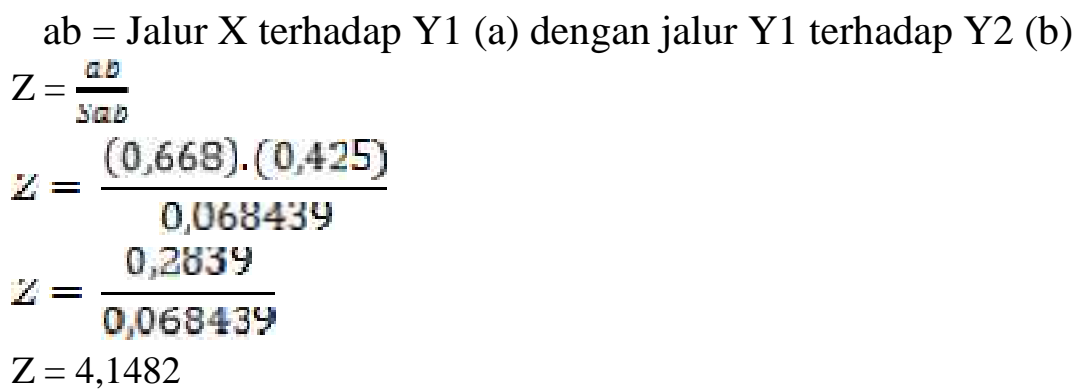

Berdasarkan perhitungan diatas, maka didapatkan nilai kalkulasi $\mathrm{Z}$ sebesar 4,1482 yang berarti bahwa nilai kalkulasi $\mathrm{Z}$ ini lebih besar dari nilai $\mathrm{Z}$ tabel sebesar 1,96 dengan tingkat signifikansi 0,000 yang lebih kecil dari 0,05. Hal ini dapat diartikan bahwa variabel kepuasan pelanggan mampu memediasi secara signifikan pengaruh merchandising terhadap loyalitas pelanggan.

Berdasarkan hasil pengujian hipotesis pertama, maka $\mathrm{H}_{1}$ diperoleh nilai probabilitas (sig) 0,000 dengan nilai koefisien beta sebesar 0,043 dan nilai $\mathrm{t}$ sebesar 4,955. Tingkat sigifikansi variabel sebesar 0,000 yang berarti lebih kecil dari taraf nyata sebesar 0,05 , maka hal ini dapat diartikan bahwa $\mathrm{H}_{0}$ ditolak dan $\mathrm{H}_{1}$ diterima. Hasil dalam penelitian ini berarti bahwa merchandising berpengaruh secara positif dan signifikan terhadap loyalitas pelanggan. Hal ini menunjukkan semakin baik merchandising (pengelolaan barang dagangan) yang di berikan Indomaret di Kota Denpasar kepada pelanggan seperti kelengkapan kategori dan merek barang yang dijual, pengelolaan pajangan barang yang dijual dan ketersediaan barang yang cukup, mampu memberikan rasa puas terhadap pelanggan sehingga pelanggan akan datang untuk belanja lagi. Hal ini berarti telah tercipta rasa loyal pelanggan terhadap Indomaret melalui produk yang dijual.

Hasil penelitian ini sesuai dengan penelitian sebelumnya yang dilakukan oleh Putra (2012) menemukan bahwa elemen-elemen dari bauran pemasaran ritel berpengaruh positif dan signifikan terhadap loyalitas pelanggan. Dan penelitian yang dilakukan oleh Hermawati (2013)menyatakan bahwa masing-masing variabel dari retail marketing mix berpengaruh positif dan signfikan terhadap loyalitas pelanggan, namun variabel harga berpengaruh positif tetapi tidak signifikan terhadap loyalitas pelanggan. Serta penelitian dari Hati \& Parlewenti (2017) yang menemukan bahwa merchandising mempunyai pengaruh positif dan signifikan terhadap loyalitas pelanggan.

Berdasarkan hasil pengujian hipotesis kedua, maka $\mathrm{H}_{2}$ diperoleh nilai probabilitas (sig) 0,000 dengan nilai koefisien beta sebesar 0,668 dan nilai $t$ sebesar 9,763. Dengan nilai sigifikansi sebesar 0,000 yang berarti lebih kecil dari taraf nyata sebesar 0,05 , maka hal ini dapat diartikan bahwa $\mathrm{H}_{0}$ ditolak dan $\mathrm{H}_{1}$ diterima. Hasil dalam penelitian ini berarti bahwa merchandising berpengaruh secara positif dan signifikan terhadap kepuasan pelanggan. Hal ini menunjukkan bahwa tanggapan pelanggan puas mengenai merchandising Indomaret di Kota Denpasar, karena tidak hanya barang yang dijual bervariasi, pengelolaan barang juga cukup baik, sehingga pelanggan mudah mendapatkan barang sesuai dengan keinginan dan tidak perlu jauh-jauh mencari tempat lain untuk berbelanja. 
Hasil penelitian ini sesuai dengan penelitian yang dilakukan oleh Pasaribu \& Sembiring (2012) menyatakan bahwa bauran pemasaran ritel berpengaruh positif dan signifikan terhadap kepuasan pelanggan. Dan penelitian dari Herawati dkk. (2013) yang menyatakan bahwa merchandising, basic principles, dan service memiliki pengaruh yang positif dan signifikan terhadap kepuasan pelanggan. Penelitian yang ditemukan Faizul (2008) bahwa indikator bauran pemasaran ritel berpengaruh positif dan signifikan terhadap kepuasan pelanggan, namun indikator harga dan pelayanan eceran berpengaruh tidak signifikan terhadap kepuasan pelanggan. Sejalan juga dengan penelitian dari Yulianti (2017) menemukan bahwa merchandising berpengaruh positif dan signifikan terhadap kepuasan pelanggan. Serta penelitian dari Hati \& Parlewenti (2017) menyatakan bahwa variabel merchandising berpengaruh signifikan terhadap kepuasan pelanggan.

Berdasarkan hasil pengujian hipotesis ketiga $\mathrm{H}_{3}$ diperoleh nilai probabilitas (sig) 0,000 dengan nilai koefisien beta sebesar 0,425 dan nilai t sebesar 5,231. Dengan nilai sigifikansi sebesar 0,000 yang berarti lebih kecil dibandingkan nilai taraf nyata sebesar 0,05 , maka hal ini dapat diartikan bahwa $\mathrm{H}_{0}$ ditolak dan $\mathrm{H}_{1}$ diterima. Hasil dalam penelitian ini berarti bahwa kepuasan pelanggan berpengaruh secara positif dan signifikan terhadap loyalitas pelanggan. Hal ini menunjukkan bahwa kepuasan pelanggan Indomaret di Kota Denpasar memiliki pengaruh yang signifikan terhadap loyalitas pelanggan. Pelanggan yang merasa puas akan kembali membeli produk di Indomaret, begitu juga sebaliknya, pelanggan yang tidak mendapatkan kepuasan disaat belanja tidak akan datang kembali untuk membeli sebuah produk. Maka untuk menciptakan sebuah sikap loyalitas perlu ada tahap dimana tingkat kepuasan yang tinggi yang dirasakan pelanggan terhadap suatu produk dan perusahaan.

Hasil penelitian ini sesuai dengan penelitian yang dilakukan oleh Musanto (2004) menyatakan bahwa kepuasan pelanggan mempunyai pengaruh positif dan signifikan terhadap loyalitas pelanggan. Penelitian Wahyuni (2008) juga menyatakan bahwa variabel kepuasan mempunyai pengaruh positif dan signifikan terhadap loyalitas. Penelitian dari Rachmawati, (2014) juga menemukan bahwa kepuasan pelanggan berpengaruh secara positif dan signifikan terhadap loyalitas pelanggan. Penelitian yang di lakukan oleh Cahyana \& Sukaatmadja (2017) juga menemukan bahwa kepuasan pelanggan berpengaruh secara positif dan signifikan terhadap loyalitas pelanggan. Sejalan juga dengan penelitian Hati \& Parlewenti (2017) menemukan bahwa kepuasan pelanggan mempunyai pengaruh positif dan signifikan terhadap loyalitas pelanggan.

Berdasarkan hasil pengujian hipotesis keempat $\mathrm{H}_{4}$ diperoleh nilai $\mathrm{Z}$ sebesar 4,1482 yang lebih besar dari $\mathrm{Z}$ tabel sebesar 1,86, hal ini menunjukkan bahwa $\mathrm{H}_{4}$ dapat diterima. sehingga dapat diartikan bahwa kepuasan pelanggan mampu memediasi pengaruh merchandising terhadap loyalitas pelanggan. Pengelolaan merchandising yang baik merupakan cara perusahaan untuk meningkatkan omset penjualan. Sehingga merchandising memegang peran penting untuk meningkatkan kepuasan pelanggan. Keuntungan perusahaan akan sendirinya tercapai apabila pelanggannya merasakan kepuasan dan loyal. Untuk itu, diperlukan pengelolaan produk yang baik. Karena pelanggan merupakan target 
utama dari sebuah kegiatan ritel yang mempunyai peranan penting untuk menghasilkan pendapatan perusahaan melalui produk yang dijual.

Hasil penelitian ini sesuai dengan penelitian yang dilakukan oleh Hati \& Parlewenti (2017), Hidayat \& Melinda (2009), serta Dei \& Sukaatmadja (2015), menyatakan bahwa kepuasan pelanggan mampu memediasi secara positif dan signifikan terhadap suatu variabel.

Implikasi hasil penelitian ini menekankan pada manfaat nyata dari hasil penelitian untuk mendorong perusahaan-perusahaan khususnya yang bergerak di bidang ritel modern agar tetap mampu menjalin hubungan jangka panjang dengan para pelanggan, salah satunya dengan cara menerapkan merchandising. Dengan menerapkan merchandising yang baik maka dapat memberikan keuntungan bagi perusahaan maupun pelanggandalam membangun kepuasan pelanggan yang akan dapat mempertahankan loyalitas pelanggan.

Merchandising telah terbukti secara positif mempengaruhi loyalitas pelanggan, oleh karena itu perusahaan dapat menerapkan merchandising pada perusahaannya sebagai salah satu strategi untuk dapat menarik pelanggan dan mempertahankan pelanggan. Penerapan merchandising secara tepat dapat mempengruhi perilaku pelanggan sehingga tetap loyal terhadap perusahaan. Ketika industri ritel mulai diramaikan dengan kehadiran pesaing-pesaing yang dapat menggoyahkan loyalitas pelanggannya, merchandising akan berperan menjaga kestabilan loyalitas.

Hasil penelitian ini membuktikan bahwa kepuasan pelangganberpengaruh terhadap loyalitas pelanggan. Diharapkan, pihak perusahaan yang pada penelitian ini adalah Indomaret dapat meningkatkan kepuasan pada pelanggan dengan memberikan pelayanan yang baik kepada pelanggan dengan menyediakan berbagai produk yang dibutuhkan dan diinginkan pelanggan serta tetap menjaga kenyamanan pelanggan ketika berbelanja. Hal ini dapat membantu perusahaan untuk dapat mempertahankan pelanggan.

Hasil penelitian ini memberikan sebuah implikasi kepada perusahaan Indomaret mengenai bagaimana pentingnya merchandising dan kepuasan pelanggan dapat mempengaruhi loyalitas pelanggan Indomaret di Kota Denpasar. Hasil yang diperoleh dari penelitian ini menunjukkan hubungan secara langsung antar variabel, salah satunya adalah variabel merchandising terhadap loyalitas pelanggan, hal ini menunjukkan bahwa semakin baik pandangan pelanggan mengenai merchandising dari produk Indomaret, maka akan berdampak baik juga bagi loyalitas pelanggan dari Indomaret itu sendiri. Selanjutnya terdapat hubungan secara langsung antar variabel merchandising terhadap kepuasan pelanggan, ini dapat diartikan bahwa merchandising juga dapat mempengaruhi kepuasan pelanggan Indomaret. Selain itu, terdapat juga hubungan secara langsung antar variabel kepuasan pelanggan terhadap loyalitas pelanggan, hal ini dapat diartikan bahwa semakin puas yang dirasakan pelanggan akan membawa pelanggan untuk menjadi loyal terhadap Indomaret. Jika pelanggan memiliki rasa loyalitas yang sangat tinggi terhadap perusahaan Indomaret walaupun ada banyak pesaing sejenis yang menyatakan perusahaan mereka lebih baik, pelanggan akan tetap memilih Indomaret. Hal ini menjadi modal yang sangat penting bagi manajemen perusahaan untuk tetap memberikan kualitas dan harga terbaik dari produk yang 
di tawarkan bagi pelanggan setianya, agar pelanggan merasa semakin tertarik dan merasa lebih memilih belanja di Indomaret dibandingkan dengan produk dari perusahaan lain.

Ruang lingkup penelitian ini hanya pada pelanggan Indomaret di Kota Denpasar, sehingga hasil penelitian tidak dapat digeneralisasi untuk pelanggan Indomaret yang berada di luar wilayah Denpasar.Jumlah responden dalam penelitian ini sangatlah terbatas, hanyalah 120 responden saja, tidak sebanding dengan keseluruhan populasi penduduk Kota Denpasar yang berjumlah 880.660 jiwa. Penelitian ini hanya dilakukan dalam jangka waktu tertentu (crosssection), sedangkan lingkungan dapat berubah setiap saat (dinamis), sehingga penelitian ini perlu dilakukan kembali di masa mendatang.

\section{SIMPULAN}

Merchandising berpengaruh positif dan signifikan terhadap loyalitas pelanggan Indomaret di Kota Denpasar, hal ini berarti bahwa semakin baik merchandising (pengelolaan barang dagangan) yang diberikan Indomaret di Kota Denpasar maka akan memberikan rasa puas terhadap pelanggan sehingga pelanggan akan datang untuk belanja lagi, dan ini berarti telah tercipta rasa loyal pelanggan terhadap Indomaret di Kota Denpasar. Merchandising berpengaruh secara positif dan signifikan terhadap kepuasan pelanggan Indomaret di Kota Denpasar, hal ini menunjukkan bahwa tanggapan pelanggan puas mengenai merchandising Indomaret di Kota Denpasar karena sesuai dengan keinginan pelanggan. Kepuasan pelanggan berpengaruh positif dan signifikan terhadap loyalitas pelanggan Indomaret di Kota Denpasar, hal ini menunjukkan bahwa semakin tinggi tingkat kepuasan pelanggan maka akan semakin tinggi pula loyalitas pelanggan terhadap Indomaret di Kota Denpasar. Kepuasan pelanggan mampu memediasi pengaruh merchandising terhadap loyalitas pelanggan Indomaret di Kota Denpasar. Hal ini berarti bahwa tanpa adanya pengaruh kepuasan pelanggan, merchandising tidak selalu berpengaruh secara positif dan signifikan terhadap loyalitas pelanggan Indomaret di Kota Denpasar.

Loyalitas pelanggan dalam penelitian ini diukur dengan menggunakan empat indikator, dan dari ke empat indikator tersebut ketidaktertarikan terhadap tawaran produk dari pesaing Indomaret mendapatkan nilai rata-rata terendah. Oleh karena itu, pihak Indomaret perlu memikirkan beberapa alternatif yang dapat diberikan kepada pelanggannya agar dapat meningkatkan kepuasan para pelanggan dan menciptakan loyalitas para pelanggan, misalnya dalam menerapkan merchandising dan strategi dalam memasarkan produk yang dijual dengan cara menyediakan produk yang lengkap, sering memberikan diskon dan memperhatikan expired dari produk yang ditawarkan serta rajin untuk memasarkan produk dan memberikan informasi jika ada diskon baik itu di media cetak maupun secara online.

Kepuasan pelanggan dalam penelitian ini diukur dengan menggunakan empat indikator, dari ke empat indikator pelayanan dari karyawan Indomaret wilayah Kota Denpasar sigap dalam melayani pelanggan mendapatkan nilai ratarata terendah. Berkaitan dengan hal ini, Indomaret wilayah Kota Denpasar diharapkan mampu memberikan pelayanan yang lebih kepada para pelanggannya, 
misalnya dengan memberikan salam kepada semua pelanggan yang berkunjung di Indomaret wilayah Kota Denpasar karena masih ada beberapa Indomaret yang mengabaikan hal tersebut dan jika pelanggan tidak menemukan barang atau produk yang dicari, karyawan harus menunjukkan langsung ke pelanggan tempat barang atau produk yang dicari tersebut sehingga pelanggan akan merasa puas berkunjung di Indomaret wilayah Kota Denpasar. Merchandising dalam penelitian ini diukur dengan menggunakan empat indikator, dimana dari ke empat indikator kelengkapan produk yang ditawarkan dan penataan layout produk mendapat nilai terendah, oleh karena itu Indomaret diharapkan dapat menyediakan produk yang lengkap serta menata secara rapi dan terstruktur produk yang ditawarkan di Indomaret wilayah Kota Denpasar sehingga pelanggan merasa mudah dan cepat dalam membeli dan menemukan produk yang dicari.

Bagi pelaku usaha sejenis, dapat mengadopsi apa yang telah dilakukan oleh Indomaret Kota Denpasar di dalam menjalankan bisnisnya, sehingga mampu bertahan di tengah persaingan pasar yang ada.Di penelitian dimasa mendatang perlu dipertimbangkan untuk menggunakan variabel lain seperti harga, demografi, kualitas produk dan sebagainya, sehingga mampu meningkatkan loyalitas pelanggan terhadap Indomaret di Kota Denpasar.Bagi peneliti selanjutnya diharapkan dapat memperluas cakupan wilayah penelitian misalnya dengan mengambil responden dan tempat penelitian tidak hanya di wilayah Denpasar, melainkan bisa mengambil lokasi penelitian di Provinsi Bali atau Indonesia mengingat Indomaret merupakan perusahaan yang sudah tersebar di seluruh Indonesia jadi sudah pasti memiliki cakupan pasar tidak hanya di wilayah Denpasar.

\section{REFERENSI}

Aryani, D., \& Rosinta, F. (2010). Pengaruh Kualitas Layanan terhadap Kepuasan Pelanggan dalam Membentuk Loyalitas Pelanggan. Bisnis \& Birokrasi, Jurnal Ilmu Administrasi Dan Organisasi, 17(2), 114-126. Retrieved from http://journal.ui.ac.id/jbb/article/viewFile/632/617

Cahyana, M. A. D., \& Sukaatmadja, I. P. G. (2017). Pengaruh Retail Marketing Mix Terhadap Kepuasan Dan Loyalitas Pelanggan. E-Jurnal Manajemen Unud, 5(1), 975-1006. Retrieved from https://ojs.unud.ac.id/index.php/Manajemen/article/view/27455

Dei, G. A. T., \& Sukaatmadja, I. P. G. (2015). Peran Brand Image Memediasi Pengaruh Kredibilitas Celebrity Endorser Terhadap Purchase Intention (Studi Pada Produk Kosmetik Etude House di Kota Denpasar). E-Jurnal Manajemen Unud, 4(5), 1206-1228. Retrieved from https://ojs.unud.ac.id/index.php/Manajemen/article/view/11603

Faizul, A. (2008). Pengaruh Strategi Bauran Pemasaran Ritel Terhadap Kepuasan Dan Hubungannya Dengan Loyalitas Pelanggan Plaza Medan Fair Di Medan. Universitas Sumatera Utara. Retrieved from https://www.academia.edu/1934107/Pengaruh_Strategi_Bauran_Pemasaran _Ritel_Terhadap_Kepuasan_Dan_Hubungannya_Dengan_Loyalitas_Pelang 
gan_Plaza_Medan_Fair_Di_Medan?auto=download

Griffin, J. (2005). Customer Loyalty: Menumbuhkan dan Mempertahankan Kesetian Pelanggan, Alih Bahasa oleh Dwi Kartini Yahya. Jakarta: Erlangga.

Hati, S. W., \& Parlewenti, N. (2017). Analysis Of Pricing And Merchandising Effect To Customer Satisfaction And It'S Affected To Customer Loyalty In Puri Batam Minimarket. Jurnal AdBispreneur, 2(1). https://doi.org/10.24198/adbispreneur.v2i1.1288

Herawati, A., Pradhanawati, A., \& Dewi, R. S. (2013). Pengaruh Bauran Pemasaran Ritel terhadap Loyalitas Pelanggan melalui Kepuasan Pelanggan Pada Konsumen Alfamart di Kecamatan Tembalang Semarang DIPONEGORO JOURNAL OF SOCIAL AND POLITIC Tahun 2013 , Hal , 1-9. Diponegoro Journal Of Social and Politic, 2(2), 1-9. Retrieved from http://ejournal-s1.undip.ac.id/index.php/

Hermawati, A. (2013). Analisis Strategi Marketing Mix Modern Ritel Terhadap Kepuasan Minat Masyarakat Dan Loyalitas Minat Masyarakat. Jurnal Manajemen Dan Akuntans, 2(3), 66-77. Retrieved from https://media.neliti.com/media/publications/112232-ID-analisis-strategimarketing-mix-modern-r.pdf

Hidayat, C., \& Melinda, P. (2009). Kontribusi Kualitas Layanan Terhadap Kepuasan Serta Dampaknya Pada Loyalitas Pelanggan. Journal The Winners, 10(2), 128-136. https://doi.org/10.21512/tw.v10i2.707

Indomaret. (2018). Retrieved August 20, 2009, from http://indomaret.co.id/

Kotler, P., \& Keller, K. L. (2009). Manajemen Pemasaran (13th ed.). Jakarta: Erlangga.

Leonard, J. (2012). Entrepreneurial Marketing Untuk Memperkuat Brand Image (Studi Kasus Coffe Toffe Radio Dalam). BINUS.

Ma'ruf, H. (2006). Pemasaran Ritel. Jakarta: PT. Gramedia Pustaka Utama.

Mardalis, A. (2005). Meraih Loyalitas Pelanggan. Benefit Jurnal Manajemen Dan Bisnis, 9(1), 111-119. https://doi.org/10.23917/benefit.v9i2.1217

Martınez-Ruiz, M. P., Jimenez-Zarco, A. I., \& Izquierdo-Yusta, A. (2010). Journal of Retailing and Consumer Services Customer satisfaction's key factors in Spanish grocery stores: Evidence from hypermarkets and supermarkets. Journal of Retailing and Consumer Services, 17, 278-285. https://doi.org/10.1016/j.jretconser.2010.02.005

Musanto, T. (2004). Faktor-Faktor Kepuasan Pelanggan dan Loyalitas Pelanggan : Studi Kasus pada CV . Sarana Media Advertising Surabaya. Jurnal Manajemen \& Kewirausahaan, 6(2), 123-136. https://doi.org/10.9744/jmk.6.2.pp.\%20123-136 
No Title. (2018). Retrieved from www.alfamartku.com

Pasaribu, D. A., \& Sembiring, B. K. F. (2012). Pengaruh Strategi Bauran Pemasaran Ritel Terhadap Kepuasan Dan Loyalitas Pelanggan Minimarket Mes Mart Syariah. Jurnal Ilmu Ekonomi Dan Bisnis, 2(1), 1-10. Retrieved from https://jurnal.usu.ac.id/index.php/jmim/article/view/2295

Putra, A. S. B. (2012). Pengaruh Retail Marketing Mix Terhadap Loyalitas Konsumen Dengan Kepuasan Konsumen Sebagai Pemoderasi. JRMB, 7(2), 97-113. Retrieved from http://ejournalfb.ukdw.ac.id/index.php/jrmb/article/view/75

Rachmawati, R. (2014). Pengaruh Kepuasan Terhadap Loyalitas Pelanggan (Sebuah Kajian Terhadap Bisnis Makanan). TEKNOBUGA, 1(1), 66-79. Retrieved from https://journal.unnes.ac.id/nju/index.php/teknobuga/article/view/6404

Sangadji, M., Etta, \& Sopiah. (2013). Perilaku Konsumen Pendekatan Praktis disertai: Himpunan Jurnal Penelitian. Yogyakarta: Andi Yogyakarta.

Semuel, H. (2006). Ekspektasi Pelanggan Dan Aplikasi Bauran Pemasaran Terhadap Loyalitas Toko Moderen Dengan Kepuasan Pelanggan Sebagai Intervening (Studi Kasus Pada Hypermarket Carrefour Di Surabaya). Jurusan Manajemen Pemasaran, Fakultas Ekonomi, 1(2), 53-64. https://doi.org/10.9744/pemasaran.1.2.

Sugiyanto, \& Yolanda. (2013). Analisis Kepuasan Pelanggan (Studi Kasus Minimarket Indomaret) Oleh : Sugiyanto dan Yolanda (Fakultas Ekonomi Universitas Borobudur). Jurnal Ekonomi, 15(2), 185-197. Retrieved from http:/ejournal.borobudur.ac.id/index.php/1/article/download/234/231

Utami, W. C. (2010). Manajemen Ritel. Jakarta: Salemba Empat.

Wahyuni, I. (2008). Pengaruh Sistem Pelayanan dan Kepuasan Terhadap Loyalitas. Nasabah BMT Mitra Usaha Mulia Tempel Sleman. Universitas Islam Negeri Sunan Kalijaga. Retrieved from http://digilib.uinsuka.ac.id/1591/1/BAB I\%2C BAB IV\%2C DAFTAR PUSTAKA.pdf

Yulianti, N. M. D. R. (2017). Pengaruh Merchandising, Basic Principles dan Retail Services terhadap Perilaku Hedonik dan Kepuasan Konsumen Discovery Shopping Mall Kuta - Bali. Media Bina Ilmiah, 11(1), 37-45. Retrieved

from https://www.researchgate.net/profile/Ni_Made_Yulianti/publication/320467 633 